\title{
ОЦЕНКА СТЕПЕНИ ЗАГРЯЗНЕНИЯ ПОЧВ В ЗОНЕ ТЕХНОГЕННОГО ВОЗДЕЙСТВИЯ НА ОКРУЖАЮЩУЮ СРЕДУ ГОРНОДОБЫВАЮЩЕГО ПРЕДПРИЯТИЯ
}

\author{
' Д.б.н. Козыбаева Ф. Е., \\ ${ }^{1}$ Д.с-х.н. Бейсеева Г. Б., \\ ${ }^{2}$ PhD докторант Саркулова Ж. С., \\ ${ }^{1}$ Казахский научно-исследовательский институт почвоведения и агрохимии им. У. У. Успанова, \\ ${ }^{2}$ Казахский Национальный Аграрный Университет, \\ Республика Казахстан, г. Алматы
}

DOI: https://doi.org/ 10.31435/rsglobal_ws/28022019/6349

\section{ARTICLE INFO}

Received: 26 December 2018

Accepted: 21 February 2019

Published: 28 February 2019

\section{KEYWORDS}

technogenesis,

the technogenic broken landscapes, bald-headed lands,

heavy metals.

\begin{abstract}
By results of researches around an arrangement of zinc plant it is established that content of gross lead in the upper 10-cm layer of earth, exceeds maximum concentration limit by 1,68 times; zinc - by 25,46 times; copper - by 1054,6 time, cadmium - by 440,9 times. As it was already mentioned, emissions of the entities of non-ferrous metallurgy are transferred to long distances. Accumulating of heavy metals in the soil at distance of $10-15 \mathrm{~km}$ is noted and is farther from a pollution source.
\end{abstract}

Citation: Козыбаева Ф. Е., Бейсеева Г. Б., Саркулова Ж. С. (2019) Ocenka Stepeni Zagryazneniya Pochv v Zone Tekhnogennogo Vozdejstviya na Okruzhayushchuyu Sredu Gornodobyvayushchego Predpriyatiya. World Science. 2(42), Vol.1. doi: 10.31435/rsglobal_ws/28022019/6349

Copyright: (C) 2019 Козыбаева Ф. Е., Бейсеева Г. Б., Саркулова Ж. С. This is an open-access article distributed under the terms of the Creative Commons Attribution License (CC BY). The use, distribution or reproduction in other forums is permitted, provided the original author(s) or licensor are credited and that the original publication in this journal is cited, in accordance with accepted academic practice. No use, distribution or reproduction is permitted which does not comply with these terms.

Введение. Особенности экологической обстановки в отдельных регионах Казахстана и возникающие экологические проблемы обусловлены местными природными условиями и характером воздействия на них промышленности, транспорта, коммунального и сельского хозяйства [1].

Состояние окружающей среды в настоящее время - самая тревожная и глобальная проблема всего человечества. Один из компонентов окружающей среды, загрязнение которого вызывает тревогу, почва. Почва - природное образование, обладающее целым набором специфических свойств. Её структура, состав и плодородный слой формируются в результате сложных биологических процессов на протяжении многих столетий. Характеристикой почвы являются плодородие, уровень которого определяет, способна ли почва обеспечить полноценный рост и развитие растений, на ней произрастающих. Естественное плодородие почвы подразумевает уровень содержания питательных веществ, рыхлость структуры и наличие живых организмов во всех ее слоях. В результате накопления солнечной энергии, которая поступает в почву за счет фотосинтеза растений, образуется плодородный слой. Повышение плодородия почвы - самый актуальный вопрос. На уровень плодородия почвы неизменно воздействует человек, и зачастую это воздействие оказывается губительным. Загрязнение почвы носит глобальный характер и может привести к непоправимым последствиям. Разрушение плодородного слоя неумолимо ведет к нарушению природного 
баланса, обмена веществ в природе. Исходя из этого, можно сказать, что загрязнение почвы может обернуться разрушением других экосистем. На сегодняшний день существует много способов загрязнения почвы. Не только пестициды способны повышать уровни загрязнения почв. Обработка почвы производится различными техническими приспособлениями, что приводит к неумолимому загрязнению почвы элементами тяжелых металлов, таких как свинец, ртуть. Эти вещества могут попасть в почву и вместе с отходами производства, и при разложении продуктов целлюлозно-бумажной промышленности. А также мелкие частицы свинца попадают в почву из выхлопных газов автомобилей. И, конечно же, не рекомендуется возделывать землю и разбивать садовые участки рядом с автотрассами. Характеристика источников загрязнения почв показывает, что главным врагом почвы является технологический процесс, продукты которого беспощадно губят её. Развитие промышленного производства приводит к росту промышленных отходов, которые в совокупности с бытовыми отходами существенно влияют на химический состав почвы, вызывая ухудшение её качества. Сильное загрязнение почвы тяжёлыми металлами вместе с зонами сернистых загрязнений, образующихся при сжигании каменного угля, приводят к изменению состава микроэлементов и возникновению техногенных пустынь. Опасность, вызываемая загрязнением тяжелыми металлами, усугубляется слабым выведением их из почвы, биоаккумуляцией и миграцией по трофическим цепям. Тяжелые металлы влияют на биологические свойства почвы: изменяется общая численность микроорганизмов, сужается их видовой состав, изменяется структура микробиоценозов и падает активность почвенных ферментов. Они также способны изменять и более консервативные признаки почв - гумусное состояние, структуру, $\mathrm{pH}$. В конце все это приводит к утрате плодородия почв [2].

Загрязнение окружающей природной среды предприятиями металлургического комплекса и их влияние на ландшафты и экосистемы связано с уровнем применяемых технологий, качеством и количеством используемого сырья, объемом и составом выбросов, сбросов и твердых отходов, положением предприятия в определенной географической зоне, подзоне и ландшафтной провинции, характером рассеивания, составом и структурой компонентов ландшафта [3].

Почвенный покров выполняет функции биологического поглотителя, разрушителя и нейтрализатора различных загрязнений. Если это звено биосферы будет разрушено, то сложившееся функционирование биосферы необратимо нарушится. Если атмосфера и водная среда могут самоочищаться, то почва таким свойством не обладает: токсичные вещества (в том числе окислы металлов) постоянно накапливаются в ней и приводят к изменению ее состава, которое соответственно вызывает изменения в растительном и животном мире. Поступление металлов в окружающую среду от техногенных источников осуществляется посредством их рассеивания во всех средах экосистем: в почве, воздухе, воде. Пути загрязнения многообразны, но важнейший из них - рассеивание техногенных выбросов через атмосферу [4]. Основным источником активного поступления тяжелых металлов на земную поверхность являются промышленные выбросы горнодобывающей, металлургической и химической промышленности. Только в результате работы металлургических предприятий на поверхность земли ежегодно поступает не менее 154656 т меди, 12150 т цинка, 89 тыс. т свинца, 12090 т никеля [5]. В районах промышленных предприятий почва в значительной степени загрязнена продуктами сжигания топлива, зола которых содержит практически все техногенные металлы. Пылевой выброс промышленных предприятий города характеризует исключительно широкая ассоциация химических элементов. Большое количество изотопов тяжелых металлов попадает в окружающую среду в виде стоков от коммунально-бытовой и производственной сфер. Валовое содержание микроэлементов в естественных незагрязненных почвах обусловлено их содержанием в материнской породе и определяется генезисом, петрохимией, фациальными различиями материнского субстрата и процессами почвообразования. Кроме того, содержание элементов в почве связано с реакцией среды и содержанием в почве органического вещества, биологическим круговоротом элементов, механическим составом с процессами миграции элементов в почвенно-грунтовом слое и с неоднородностью видового состава растительного покрова $[6,7,8]$.

Главными компонентами формирующейся в условиях урбанизации экосистемы являются почвы. Почвы, в отличие от воздушной и водной сред, испытывают более сильное 
воздействие урбанистического прессинга, быстро поглощают из окружающей среды поллютанты и очень медленно их трансформируют $[9,10]$.

Почвы в городах развиваются под воздействием тех же факторов почвообразования, что и природные почвы, но техногенный фактор здесь оказывает первоочередное влияние. Хозяйственная деятельность человеческого общества в крупных и малых городах приводит к существенному и часто необратимому изменению почвенного покрова $[11,12]$.

Таким образом, проблема загрязнения почв ТМ является одной из «острых» проблем экологии и является объектом дальнейшего пристального изучения.

Цель исследования: изучение влияния горной, металлургической и перерабатывающей промышленностей на окружающую среду.

Объекты и методы исследований. Объектом исследования являются территории, находящиеся под влиянием выбросов предприятий перерабатывающей горнорудной промышленности г. Риддера ВКО. Влияние цинкового завода на окружающие ландшафты. Цинковый завод расположен в черте города (Рисунок 1).

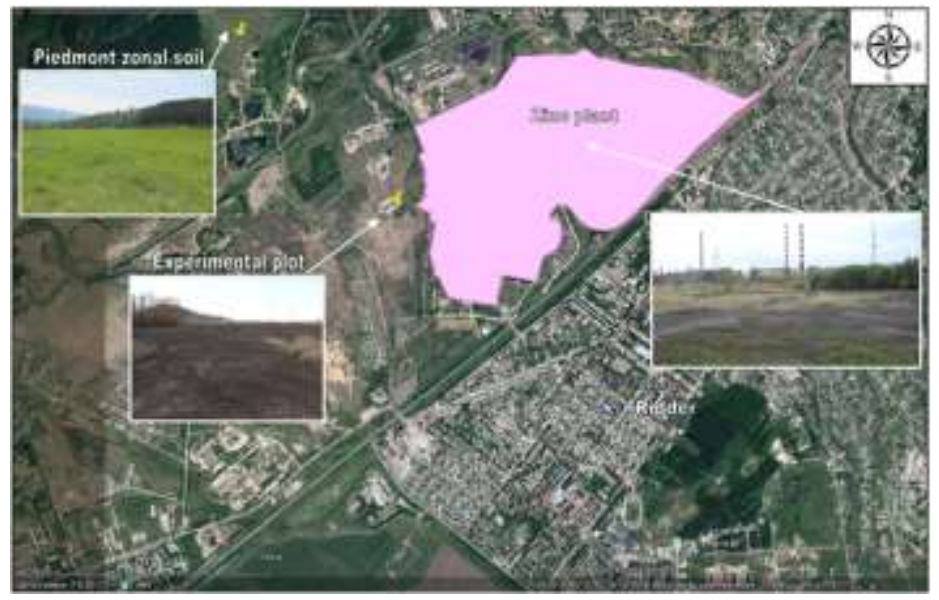

Рис. 1. Карта схема объекта исследования

Методы исследования - полевые и лабораторно-аналитические. Рекогносцировочный объезд территории, определение источников загрязнения. Отбор проб почв проводился в направлении роза ветров в 10-и точках и верхней, средней и нижней части исследуемого участка. Определение тяжелых металлов и других химических элементов в почвах проводились ядерно-физическими и атомно-абсорбционными методами. Экологический анализ уровня опасности загрязнения городских почв комплексом тяжелых металлов проведен по суммарному показателю химического загрязнения (Zc), предложенному СанПиН 4266-87 и отражающему наглядную дифференциацию химического загрязнения почвенного покрова в пределах урбанизированных территорий [13]. Суммарный показатель загрязнения почв $(\mathrm{Zc})$ вычислялся по наиболее распространенным тяжелым металлам, показавшим высокие концентрации в почвах района исследований, по следующей формуле [14, 15]:

$$
Z c=\sum_{t=1}^{n} K c
$$

$n$ - число суммируемых элементов, $K c$ - коэффициент концентрации химического вещества, равный отношению содержания $i$-металла в почве загрязненной территории к фоновому.

Результаты и их обсуждение. Для ТМ почва является емким акцептором, занимающим место в круговороте химических загрязнителей в биосфере. Почва находится в постоянном взаимодействии с другими экологическими системами - атмосферной, гидросферой, растительным миром и является важным источником поступления ТМ в организм человека. Поступившие в почву ТМ в процессе активного их извлечения из почвы корневой системой, могут накапливаться в сельскохозяйственных культурах, а при вымывании поверхностными 
водами концентрируется в водных организмах, донных отложениях. Установлено, что металлы сравнительно быстро накапливается в почве и крайне медленно из нее удаляются. Первый период полуудаления (т.е. удаления половины от начальной концентрации) ТМ значительно варьирует у различных элементов и занимает весьма продолжительный период времени: для цинка - от 70 до 510 лет; кадмия - от 13 до 110 лет, меди - от 310 до 1500 лет, свинца - от 770 до 5900 лет. Изучению ТМ в почве посвящено большое количество исследований. Подробно рассмотрены источники поступления ТМ в почву и проанализировано валовое содержание целого ряда металлов [16]. На концентрацию ТМ оказывают влияние свойства почв. В почвах тяжелого гранулометрического состава, как правило, обнаруживаются более высокие концентрации ТМ, песчаные и супесчаные почвы в меньшей степени накапливают их. Значительное влияние оказывают кислотно-основные свойства почв. В условиях кислой среды нерастворимая часть фракции ТМ переходит в растворимые формы, тем самым концентрация ТМ в кислых почвах может нарастать [17]. Приоритетными загрязнителями исследуемой территории являются тяжелые металлы как результат увеличения выбросов промышленных предприятий загрязняющих значительных территорий. Это обусловливает интенсивность и неоднородность почвенных загрязнений. Почвы опытного участка в верхних горизонтах содержат тяжелые металлы, превышающие ПДК в два-десять раз. Основными загрязнителями являются цинк, свинец, медь. При загрязнении прочнее всего в почве закрепляются медь, свинец. Фиксация их происходит за счет комплексобразования с органическим веществом и в меньшей степени за счет специфической сорбции минеральными компонентами, цинк и кадмий в почве связываются слабее [18]. В почвенных образцах, отобранных из разрезов, заложенных возле цинкового города Риддер по профилю в нижних горизонтах наблюдается снижение содержания тяжелых металлов.

На эродированном участке для определения тяжелых металлов в поверхностном слое почвы в 5 точках были отобраны образцы почв на глубину 0-10 см. Данные показывают, что чем ближе источник загрязнения, тем выше содержания тяжелых металлов (таблица 1). По статистическим данным вариационный коэффициент (V,\%) по цинку составляет 4,3 - 44,3, по меди 13,3 - 53,4, по свинцу 12-82,2 \% (таблица 2).

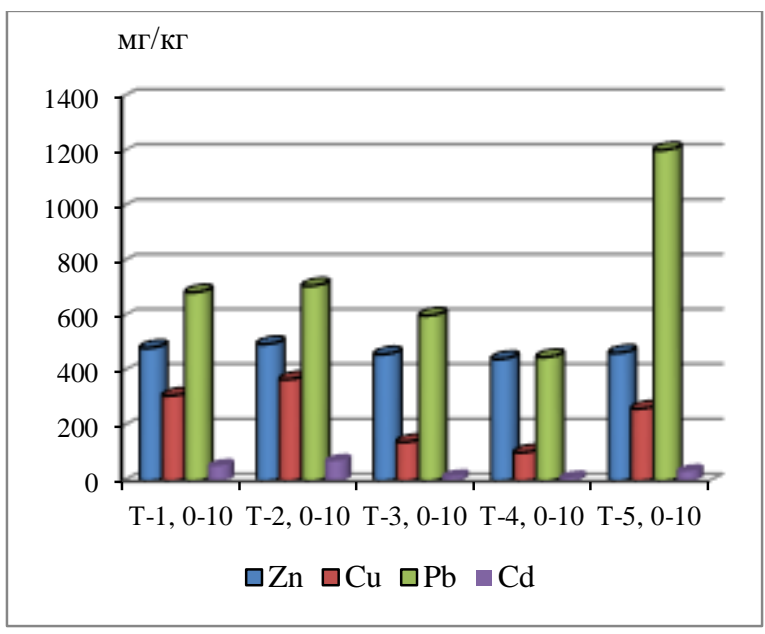

1

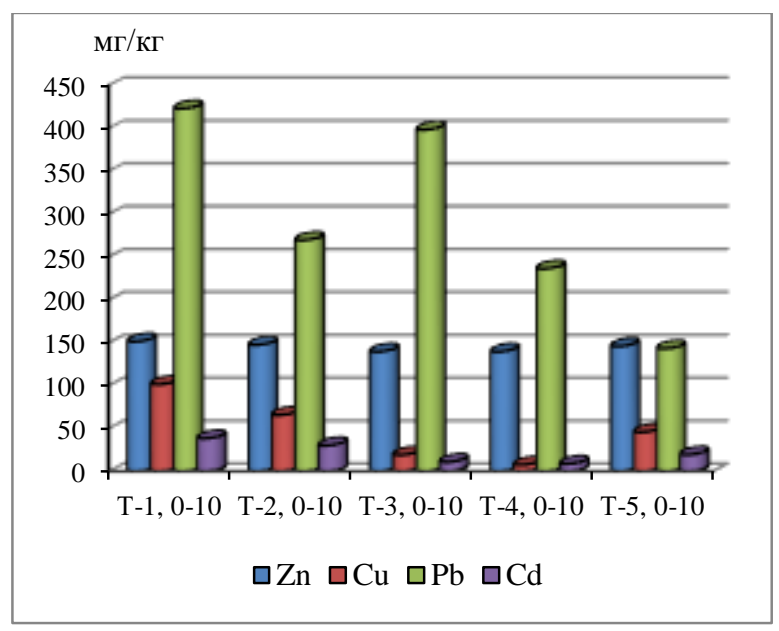

2

Рис. 2. Содержание тяжельх металлов в почвах, мг/кг. Риддерский цүинковый завод, эродированнылй участок: 1 -валовые формы TM; 2 - подвижные формы ТМ 
Таблица 1. ПДК тяжелых металлов в почве объекта исследования

\begin{tabular}{|c|c|c|c|c|c|c|c|c|c|c|c|c|c|c|c|c|c|}
\hline \multirow[b]{2}{*}{ 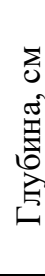 } & \multicolumn{9}{|c|}{ Подвижные формы, мг/кг } & \multicolumn{8}{|c|}{ Валовые формы, мг/кг } \\
\hline & งี & 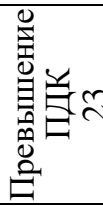 & 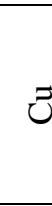 & 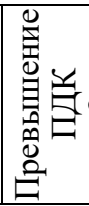 & $\hat{2}$ & 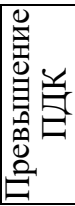 & & & 造 & సี & 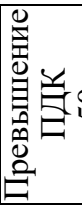 & $\mathcal{Z}$ & 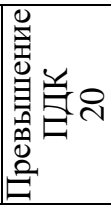 & $\hat{2}$ & 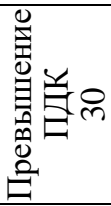 & 己 & 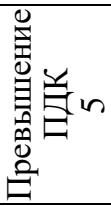 \\
\hline \multicolumn{18}{|c|}{ Риддерский цинковый завод, эродированный участок } \\
\hline $\begin{array}{l}0 \\
1 \\
0 \\
i \\
1\end{array}$ & $\stackrel{n}{n}$ & r & $\stackrel{n}{0}$ & $\stackrel{+}{m}$ & $\begin{array}{l}\hat{\tilde{I}} \\
\hat{f}\end{array}$ & $\stackrel{2}{\circ}$ & & & 2 & 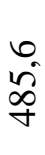 & 으 & $\frac{0}{i}$ & $\underline{0}$ & $\begin{array}{l}0 \\
\infty \\
\infty \\
0\end{array}$ & $\overparen{\sim}$ & $\begin{array}{l}\text { ñ } \\
n\end{array}$ & $\exists$ \\
\hline $\begin{array}{l}0 \\
0 \\
0 \\
\hat{N} \\
\stackrel{1}{H}\end{array}$ & 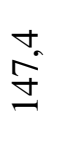 & 0 & vi & ป & $\begin{array}{l}n \\
\text { ồ } \\
\text { and }\end{array}$ & 年 & & & 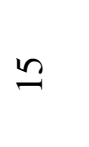 & $\begin{array}{l}0 \\
\text { gे }\end{array}$ & 으 & $\frac{0}{\infty}$ & 2 & $\begin{array}{l}\stackrel{0}{i} \\
\stackrel{\pi}{1}\end{array}$ & $\stackrel{\sim}{\Delta}$ & $\stackrel{\sim}{2}$ & $\stackrel{n}{n}$ \\
\hline $\begin{array}{l}0 \\
1 \\
0 \\
\stackrel{p}{H}\end{array}$ & ڤे & 0 & $\stackrel{2}{2}$ & 0 & $\begin{array}{l}\text { No } \\
\text { ळे } \\
\text { mे }\end{array}$ & 8 & & & $n$ & 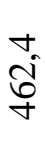 & $a$ & $\stackrel{\sim}{\tilde{f}}$ & r & סे & ণి & $\stackrel{\infty}{0}^{\infty}$ & $m$ \\
\hline 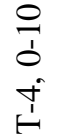 & $\stackrel{n}{2}$ & 0 & $\stackrel{6}{\sim}$ & $m$ & $\begin{array}{l}\text { mo } \\
\text { ते } \\
\text { ते }\end{array}$ & ले & con & & 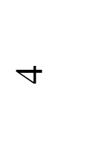 & $\begin{array}{l}6 \\
\text { fo } \\
\dot{f}\end{array}$ & $a$ & $\begin{array}{l}\infty \\
\dot{0} \\
\stackrel{0}{ }\end{array}$ & $n$ & $\begin{array}{l}\vec{v} \\
\text { iv } \\
\dot{f}\end{array}$ & $\stackrel{n}{n}$ & $\stackrel{+}{\mathrm{I}}$ & N \\
\hline $\begin{array}{l}0 \\
\vdots \\
0 \\
\text { in } \\
1\end{array}$ & $\begin{array}{l}\infty \\
\text { in }\end{array}$ & 0 & $\hat{f}$ & 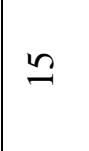 & $\stackrel{\sim}{\tilde{g}}$ & 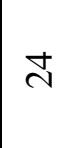 & 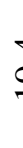 & & $\varrho$ & రీ & $a$ & $\begin{array}{l}+ \\
\text { đ্ } \\
\text { N }\end{array}$ & 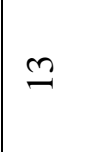 & 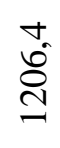 & \& & $\hat{\delta}_{0}^{0}$ & $r$ \\
\hline
\end{tabular}

Таблица 2. Вариационно-статистические показатели распространения валовых форм Zn, $\mathrm{Cu}, \mathrm{Pb}, \mathrm{Cd}$

\begin{tabular}{|c|c|c|c|c|c|c|c|c|c|c|c|c|c|c|c|c|c|}
\hline \multirow{2}{*}{ 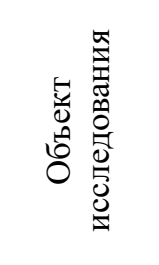 } & \multirow{2}{*}{ 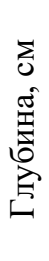 } & \multicolumn{4}{|c|}{ సี } & \multicolumn{4}{|c|}{$\vec{U}$} & \multicolumn{4}{|c|}{$\hat{2}$} & \multicolumn{4}{|c|}{$\bar{v}$} \\
\hline & & $\mathrm{n}$ & $\sum^{ \pm}$ & $\begin{array}{l}\stackrel{0}{0} \\
\dot{z}\end{array}$ & $\stackrel{\circ}{\circ}$ & $=$ & $\stackrel{\Xi}{ \pm}$ & $\begin{array}{l}0 \\
\dot{z}\end{array}$ & $\stackrel{\circ}{\circ}$ & $=$ & $\sum_{\sum}^{ \pm}$ & $\begin{array}{l}\dot{0} \\
\dot{3}\end{array}$ & $\begin{array}{l}\circ \\
\therefore\end{array}$ & $=$ & $\stackrel{\Xi}{\tilde{y}}$ & $\begin{array}{l}0 ? \\
z\end{array}$ & $\begin{array}{l}\stackrel{0}{2} \\
\stackrel{1}{2}\end{array}$ \\
\hline 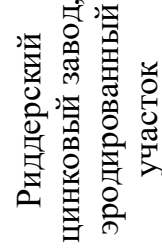 & $\begin{array}{l}0 \\
0\end{array}$ & in & $\begin{array}{l}\text { to } \\
\text { if } \\
+1 \\
\text { s. } \\
\text { in }\end{array}$ & $\begin{array}{l} \pm \\
\infty \\
i n\end{array}$ & - & in & 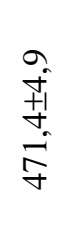 & $\vec{\lambda}$ & $\underset{-}{\mathbb{O}}$ & in & $\begin{array}{l}\infty \\
\text { +1 } \\
\text { N } \\
\text { ᄋे } \\
\text { ป̂ }\end{array}$ & ஸे & $\stackrel{0}{0}$ & in & $\begin{array}{l}\vec{\sim} \\
+1 \\
\dot{\sim} \\
\infty \\
\infty\end{array}$ & $\frac{\hat{n}}{2}$ & $\stackrel{\substack{\tilde{r} \\
i}}{ }$ \\
\hline
\end{tabular}

Наш исследуемый опытный участок имеет с поверхности уклон 15-20․ Поэтому мы условно разделили территорию опытного участка на три части верхняя, средняя и нижняя части участка (Рисунок 3 ). 

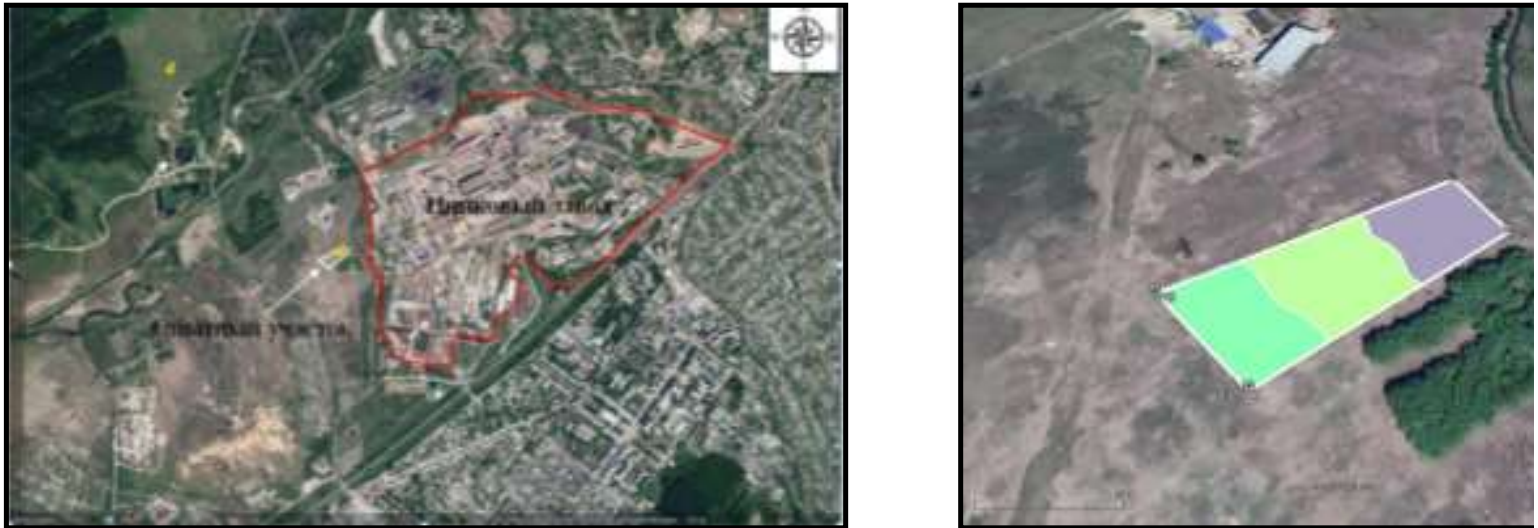

Рис. 3. Карта-схема опьтного участка

Условные обозначения

$\square$ - Верхняя часть участка $\square$ - Средняя часть участка $\square$ - Нижняя часть участка

Валовое содержание тяжелых металлов в почвенной среде является фактором емкости, отражающим потенциальную опасность загрязнения почв, растений, инфильтрационных и поверхностных вод [19].

По результатам наших исследований в районе расположения предприятий цветной металлургии установлено, что содержание валового свинца в верхнем 10 см слое почвы, превышает контрольные зональные значения в 707 раз; кадмия - в 188 раз; цинка - в 2302 раза (таблица 3).

Таблица 3. Валовое содержание тяжелых металлов почвы исследуемой территории, МГ/КГ

\begin{tabular}{|c|c|c|c|c|c|c|c|}
\hline \multirow[t]{2}{*}{ Место отбора образцов } & \multirow{2}{*}{$\begin{array}{l}\text { Глубина, } \\
\text { см }\end{array}$} & \multicolumn{6}{|c|}{ Валовое содержание элемента, мг/кг } \\
\hline & & $\mathrm{Cd}$ & $\mathrm{Cd}$ & $\mathrm{Cd}$ & $\mathrm{Cd}$ & $\mathrm{Cd}$ & $\mathrm{Cd}$ \\
\hline \multicolumn{8}{|c|}{ Верхняя часть территории } \\
\hline Участок с суданской травой & $0-10$ & 53,8 & 1802,8 & 538,6 & 71,6 & 3,5 & 0,6 \\
\hline $\begin{array}{lcc}\text { Участок под ясенем } & \text { с } \\
\text { внесением биоугля } & & \end{array}$ & $0-10$ & 35,5 & 781,3 & 13874,0 & 211,8 & 4,4 & 0,2 \\
\hline $\begin{array}{llll}\text { Участок под } \\
\text { жимолостью }\end{array}$ & $0-10$ & 40,2 & 1209,0 & 20000,0 & 341,2 & 4,7 & 0,9 \\
\hline $\begin{array}{llll}\text { Участок под } & \text { березой } & \text { и } \\
\text { жимолостью } & & \end{array}$ & $0-10$ & 0,4 & 11,3 & 120,0 & 0,3 & 3,3 & 0,7 \\
\hline Участок с суданской травой & $0-10$ & 53,8 & 1802,8 & 538,6 & 71,6 & 3,5 & 0,6 \\
\hline \multicolumn{8}{|c|}{ Средняя часть территории } \\
\hline $\begin{array}{llc}\text { Участок } & \text { с } \quad \text { травосмесью } \\
\text { внесением биоугля } & \\
\end{array}$ & $0-10$ & 32,2 & 141,3 & 7400,0 & 19,2 & 1,3 & 0 \\
\hline $\begin{array}{llll}\text { Участок с } & \text { травосмесью } \\
\text { внесением биоугля } & \end{array}$ & $5-15$ & 18,2 & 200,7 & 7200,0 & 25,6 & 3,9 & 0 \\
\hline $\begin{array}{lll}\text { Участок } & \text { с } & \text { травосмесью } \\
\text { внесением биоугля } & \\
\end{array}$ & $10-20$ & 0,6 & 9,7 & 440,0 & 0,6 & 2,6 & 0,6 \\
\hline Участок с высевом донника & $0-10$ & 56,3 & 2545,6 & 58000,0 & 881,8 & 3,2 & 0,6 \\
\hline \multicolumn{8}{|c|}{ Нижняя часть территории } \\
\hline Участок под березой и сиренью & $0-10$ & 36,5 & 386,4 & 11050,0 & 42,6 & 2,8 & 0 \\
\hline Участок под березой и сиренью & $0-10$ & 8,9 & 55,7 & 4200,0 & 2,3 & 2,7 & 0,6 \\
\hline Участок под шиповником & $0-10$ & 39,6 & 392,6 & 10400,0 & 60,7 & 1,9 & 0,7 \\
\hline $\begin{array}{l}\text { Участок в } 400 \text { м вверх от } \\
\text { исследуемой территории }\end{array}$ & $0-10$ & 22,4 & 445,0 & 8200,0 & 58,3 & 2,4 & 0,4 \\
\hline \multicolumn{8}{|c|}{ Контрольный участок в 25 км на север. } \\
\hline $\begin{array}{l}\text { С. Бутаково. Чернозем горный. } \\
\text { Гор. А (пах) }\end{array}$ & $0-20$ & 0,4 & 3,6 & 25,2 & 0,4 & 0,9 & 0,8 \\
\hline С. Бутаково. Чернозем горный & $80-90$ & 0,1 & 1,8 & 3,1 & 0,3 & 0,9 & 0 \\
\hline
\end{tabular}


На угодьях, расположенных рядом с исследуемым участком, в верхнем 10 см слое содержится свинца - 445 мг/кг (в зональной почве - 3,6 мг/кг); кадмия - 22,3 мг/кг (соответственно 0,38 мг/кг); цинка - 8200 мг/кг (около 25 мг/кг). То есть на несколько порядков превышает значения зональных почв. При техногенном загрязнении изучаемых в районе комбината почв химические элементы накапливаются главным образом в пределах $0-10 ; 0-$ 20 см. На контрольных участках, расположенных в 25 км от зоны исследования, в горных черноземах выщелоченных содержание тяжелых металлов незначительное, по сравнению с черноземом деградированным. Большое количество тяжелых металлов, превышающее контроль в порядки, поступило в почву в результате выбросов горно-металлургического цинкового завода. Так как при техногенном загрязнении изучаемых в районе комбината почв химические элементы накапливаются главным образом в верхней части профиля, то основное внимание уделялось изучению поверхностной части почвы. Источником техногенного загрязнения тяжелыми металлами являются атмосферные выбросы и жидкие стоки промышленных предприятий. Добыча и переработка полезных ископаемых и, как следствие, развитие промышленного производства привела к тому, что в почвах, окружающих производства и места добычи ландшафтов значительно превышается содержание тяжелых металлов.

По данным И. Торнтона в почве одного из предместий Лондона содержится свинца 13680 мг/кг, цинка - 13120, меди - 2320, кадмия - до 40 мг/кг [20]. Общегородскими химическими элементами-загрязнителями являются $\mathrm{Sn}$ и $\mathrm{Pb}$; часто встречающимися $-\mathrm{Cu}, \mathrm{Zn}$, $\mathrm{Cd}$; локальными - $\mathrm{Cr}$, Mo, Ni, Mn, Co, Bi, As, Sr [21]. В деградированных черноземах исследуемой территории содержание свинца 9,7-2545,6 мг/кг; цинка - 120-58000 мг/кг; кадмия - 0,4-56,4 мг/кг; меди - 0,3-881,8 мг/кг (таблица 3). Данные элементы являются и общегородскими химическими элементами-загрязнителями. Считается, что зона экологического неблагополучия вокруг городов с интенсивными производствами имеет ширину около 5 км [4]. Хотя могут быть и исключения. Предполагается, что техногенное загрязнение почвенного покрова тяжелыми металлами в городе Риддер распространяется, преимущественно, на 5-6 км от городской черты, и шлейфом до 15-25 км по направлению господствующих ветров, на восток от завода в сторону города и зависит от особенности рельефа. По данным исследователей, в радиусе 1 км от источника загрязнения на почве оседает $1-3 \%$ тяжелых металлов от их количества в атмосферных выбросах, а доля осевшего на почву цинка в радиусе 10 км от цинкового завода не превышала $10 \%$. Полученные результаты определяют степень техногенного влияния промышленных комплексов на окружающую среду. В процессе исследования были выявлены приоритетные тяжелые металлы, их источники поступления в систему почва-растение. Основными загрязняющими элементами являются свинец, цинк и медь (таблица 4, рисунок 4). Источниками загрязнения природных экосистем являются свинцовый завод (Pb, $\mathrm{Zn})$; цинковый завод $(\mathrm{Zn}, \mathrm{Pb}, \mathrm{Cu})$; - хвостохранилище $(\mathrm{Pb}, \mathrm{Zn}, \mathrm{Cu})$ г.Риддер.Суммарное загрязнение почвы тяжелыми металлами в зоне влияния свинцового, цинкового заводов и хвостохранилища г. Риддер составляет $(Z c)=88,71$, что позволяет отнести, исследуемую территорию к категории опасного уровня загрязнения почв. Суммарный показатель $(Z c)$ загрязнения почв равен сумме коэффициентов концентраций химических элементов и выражается следующей формулой:

$$
Z c=\sum_{t=1}^{n} K c
$$

$n$ - число суммируемых элементов, $K c$ - коэффициент концентрации химического вещества, равный отношению содержания $i$-металла в почве загрязненной территории к фоновому [14].

Таблица 4. Экологический анализ состояния почв по суммарному показателю загрязнения

\begin{tabular}{|c|c|c|}
\hline Город & Средневзвешенная величина Zc & Уровень загрязнения почв \\
\hline $\begin{array}{c}\text { Естественные ненарушенные } \\
\text { почвы }\end{array}$ & 4,0 & Допустимый $(<16)$ \\
\hline $\begin{array}{c}\text { Риддер, техногенно } \\
\text { загрязненные почвы }\end{array}$ & 88,71 & Опасный $(32-128)$ \\
\hline
\end{tabular}




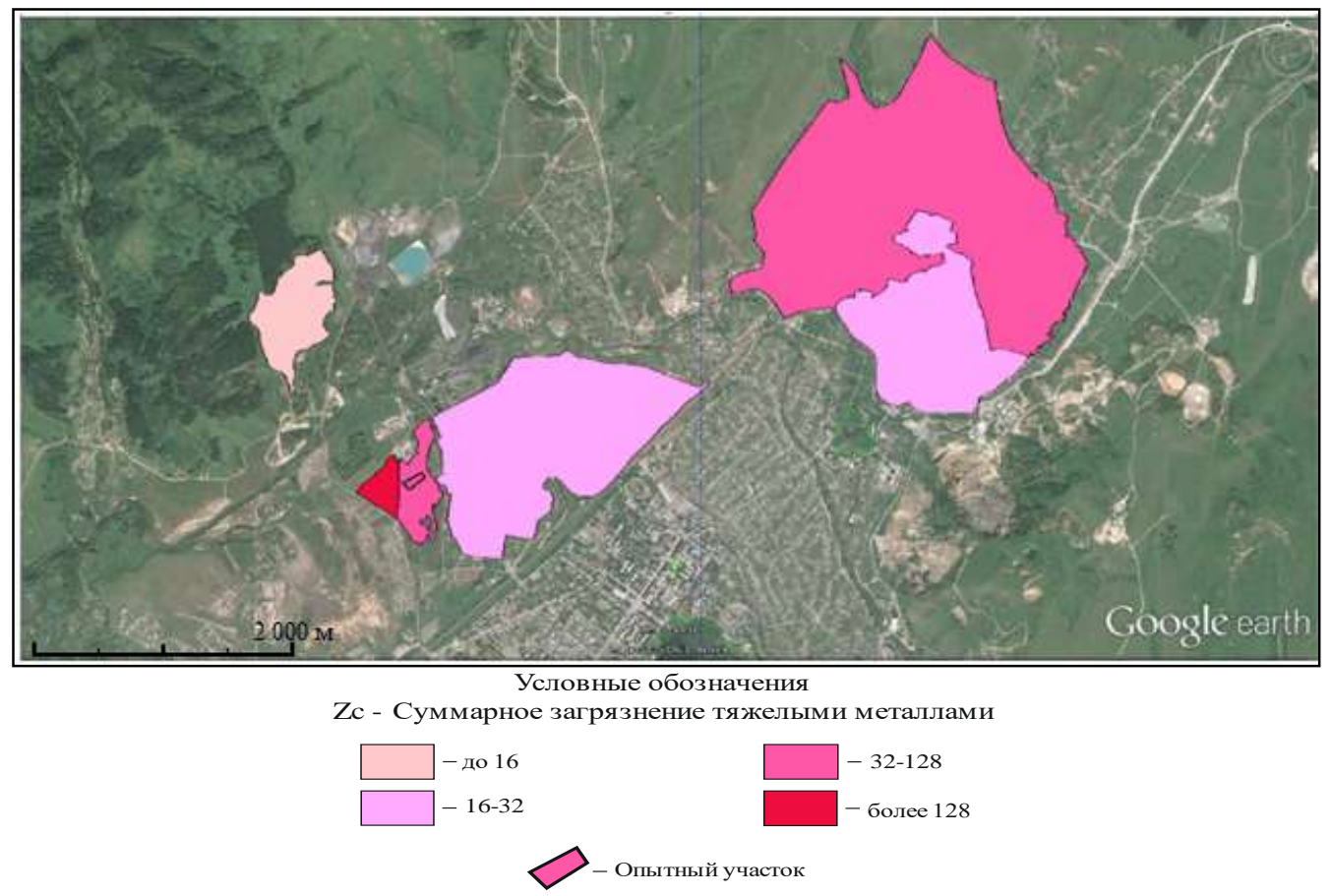

Рис. 4. Карта-схема суммарного загрязнения основными тяжелыми металлами на территории исследуемых объектов:Риддерского цинкового, свинцового заводов и хвостохранилища

Выводы. Таким образом, в связи с интенсивным ростом и развитием промышленности за последние годы значительно увеличилось и продолжает нарастать поступление в окружающую среду ТМ техногенного происхождения. Аналитические данные позволили определить содержание тяжелых металлов в почве как валовых, так и подвижных их форм. Приоритетными элементами загрязнения являются цинк, свинец, медь и кадмий. По результатам анализов содержание тяжелых металлов в исследуемой черноземной выщелоченной почве по всем элементам превышает предельно допустимые нормы. Повышенная концентрация тяжелых металлов отмечается в верхних слоях. С цинкового завода идут выбросы тяжелых металлов, что негативно сказывается на почвенный и растительный покров района цинкового завода. Этот участок сильно загрязнен. Высокое загрязнение сильно сказывается на растительном покрове. На контрольных участках, расположенных в 25 км от зоны исследования, в горных черноземах выщелоченных содержание тяжелых металлов незначительное, по сравнению с черноземом деградированным. Это говорит о том, что такое большое количество тяжелых металлов, превышающее контроль в порядки, поступило в почву в результате выбросов горно-металлургического цинкового завода.

\section{ЛИТЕРАТУРА}

1. Сихимбаев М.Р, Ханов Т.А. Пути обеспечения экологической безопасности в нефтедобывающих регионах Казахстана // Международный журнал прикладных и фундаментальных исследований. 2014.

http://www.rae.ru/upfs/?section=content\&op=show_article\&article_id=5647

2. Агибаева А.К., Алтынсариев А.Ж., Сембиева А.А. Фиторемедиация почв, загрязненных токсичными отходами металлургического роизводства // ҚазҰТУ хабаршысы. - №2. - 2013. - С. 3-7.

3. Груздев В.С. Влияние черной металлургии на состояние окружающей среды // Землеустройство, кадастр и мониторинг земель. - 2008. - № 4. - С. 47-51.

4. Ильин В.Б. Тяжелые металлы и неметаллы в системе почва-растение. - Новосибирск: Изд-во СО PAH. - 2012. $-220 \mathrm{c}$.

5. Минеев В.Г. Экологические проблемы агрохимии: Учеб. пос. для студентов вузов, обучающихся по специальности агрохимия и почвоведение. - М.: МГУ. - 1988. - 282 с.

6. Цыганок С.И.Экологические проблемы использования и рекультивации агроландшафтов, подвергнутых техногенной эмиссии //Сб. науч. тр. 1996. Т. 13. С. $42-45$. 
7. Beiseyeva G., Abuduwali J. (2013). Migration and accumulation of heavy metals in disturbed landscapes in developing ore deposits, East Kazakhstan //J. AridLand - 5(2): - pp.180-187. doi: 10.1007/s40333-0130160-4 jal.xjegi.com; www.springer.com/40333.

8. Бейсеева Г.Б. Шығыс Қазақстандағы техногендік- бүлінген жерлердің топырақ-өсімдік-су жүйесіндегі ауыр металдардың биогеохимиялық миграциясы мен аккумуляциясы. Докт. дисс. авторефераты 03.00.27 - топырақтану. - Алматы. - 2010. - 48 б.

9. Ревич Б.А., Сает Ю.Е. и др. Геохимическая оценка загрязнения территорий городов химическими элементами. - М. - 1982. - 112 с.

10. Трофимова Т.А. Применение посевов горчицы сарептской в целях фиторемидиации техногенно загрязненных тяжелыми металлами светло- каштановых почв южной пригородной агропромзоны г. Волгограда: автореф. дис. ... канд. сельскохоз. наук. - Волгоград. - 2009. - 26 с.

11. Джирард Д.Е. Основы химии окружающей среды / пер. с англ. В.И. Горшкова; под ред. В.А. Иванова. - М.: Физматлит. - 2008. - 640 с.

12. Добровольский В.В., Савельева Л.Е. Автотранспортное загрязнение свинцом окружающей среды за рубежом // Геохимия техногенного преобразования ландшафтов. - М. - 1978. - С. 6-20.

13. СанПиН 4266-87. Методические указания по оценке степени опасности загрязнения почвы химическими веществами. М.: Минздрав СССР, 1987. 21 с.

14. Федорец Н.Г., Медведева М.В. Методика исследования почв урбанизированных территорий. Петрозаводск: Карельский научный центр РАН, 2009. 84 с.,

15. Методические указания по оценке городских почв при разработке градостроительной и архитектурно-строительной документации. М., 2003. 24 с.

16. Алексеев Ю.В.Тяжелые металлы в почвах и растениях. -Л. -1987. - 142 с., Ковда В.А. Биогеохимия почвенного покрова. М.: Наука. - 1985. 263 с., Мудрый И.В. Влияние химического загрязнения почвы на здоровье населения // Гигиена и санитария. - 2008. - №4. - С. 32-37.

17. Иванов В.В. Геохимия рассеянных элементов $\mathrm{Ga}, \mathrm{Ge}, \mathrm{Cd}, \mathrm{In}, \mathrm{Tl}$ в гидротермальных месторождениях. -М.: Недра. - 1966. - 389 с.

18. Понизовский А. А., Мироненко Е. В. Механизмы поглощения свинца (II) почвами // Почвоведение. 2001. - № 4. - С. 418-429.

19. Ларионов М.В. Особенности накопления техногенных тяжелых металлов в почвах городов среднего и нижнего Поволжья// Вестник Томского государственного университета. 2013. № 368. С. 189-194

20. Thornton J. Metal contamination of soils in UK urban gardens: implications to health // Contaminated soils. - Dordrecht, Boston, Lancaster: Martinus Nijhoff Publ. - 1986. - P. 203-207.

21. Ильин В.Б., Сысо А.И. Микроэлементы и тяжелые металлы в почвах и растениях Новосибирской области. - Новосибирск: Изд-во СО РАН. 2001. - 229 с. 